\title{
A sinodalidade como referencial do estatuto teológico das conferências episcopais
}

\section{Synodality as a reference for the theological status of episcopal conferences}

\section{Resumo}

Diante da falta de reconhecimento e até da negação do estatuto teológico das Conferências Episcopais, em um primeiro momento, este estudo mostra a relação intrínseca entre sinodalidade eclesial e colegialidade episcopal. E mais que isso, se fundamenta, teologicamente, o primado da sinodalidade eclesial em relação à colegialidade episcopal ou do sensus fidelium de todo o Povo em relação ao Colégio dos bispos. Em um segundo momento, se inter-relaciona sinodalidade eclesial, colegialidade episcopal e magistério, partindo da premissa que como a colegialidade episcopal se situa no seio da sinodalidade eclesial, também a função magisterial se dá no seio do Povo de Deus, fruto de um mútuo dar e receber entre todos os membros da comunidade, no respeito pelo lugar que cada um ocupa na Igreja. Como a Igreja é una, também uno é o magistério, ainda que em diferentes níveis, incluídas as Conferências Episcopais, dado que o Povo de Deus é um povo organizado.

Palavras-chave: Sinodalidade. Colegialidade. Vaticano II. Conferências Episcopais. Bispos. 


\begin{abstract}
In the face of the lack of recognition and even denial of the theological statute of Episcopal Conferences, this study shows the intrinsic relation between ecclesial synodality and episcopal collegiality. And more than that, it is theologically based the primacy of the ecclesial synodality in relation to the episcopal collegiality or the sensus fidelium of the whole People of relation to the College of bishops. In a second moment, it is interrelated ecclesial synodality, episcopal collegiality and magisterium, starting from the premise that as episcopal collegiality is situated in the heart of ecclesial synodality, the magisterial function also occurs in the bosom of the People of God, the fruit of a mutual give and receive among all the members of the community, respecting the place that each one occupies in the Church. As the Church is one, one is also the magisterium, although at different levels, including the Episcopal Conferences, since the People of God is an organized people.
\end{abstract}

Keywords: Synodality. Collegiality. Vatican II. Episcopal Conferences. Bishops.

\title{
Introdução
}

Desde a primeira-hora de seu pontificado, o Papa Francisco pôs em marcha um processo de reforma de estrutura da Igreja, começando pela Cúria romana ou pelo ministério do Primado. O referencial teológico-pastoral é a sinodalidade como componente do ser e do quehacer da Igreja. Entre os organismos eclesiais que são expressão do exercício da sinodalidade eclesial, estão as Conferências Episcopais, tanto nacionais como continentais, como é o caso da Igreja na América Latina.

Inseridas no seio do exercício da colegialidade episcopal, as Conferências Episcopais são um sujeito eclesial relativamente recente. Até porque os Estados nacionais só nasceram na esteira dos ideais democráticos, consolidados pela Revolução Francesa de 1789. Elas nasceram da livre iniciativa dos Bispos para fazer frente aos desafios pastorais decorrentes do surgimento das novas circunscrições civis e, em pouco tempo, ganharam proporção e importância, contribuindo significativamente para a dinamicidade e organicidade da vida da Igreja, tanto em âmbito nacional como continental. Na América Latina, elas desempenharam 
um papel preponderante, particularmente no processo de recepção do Concílio Vaticano II e na tessitura da tradição eclesial libertadora em torno a Medellín, ainda que em meio a tensões e conflitos com a Cúria romana.

Entretanto, com o processo de involução eclesial em relação à renovação do Concílio Vaticano II, instaurado na Igreja nas últimas três décadas, as Conferências Episcopais passaram a ter uma relevância cada vez menor. Além de terem passado por uma mudança profunda no perfil de seus membros durante os últimos dois pontificados, já por ocasião da celebração dos 25 anos do Concílio Vaticano II, elas tiveram seu estatuto teológico questionado pela Congregação da Doutrina da Fé. Apesar das reações e do mal-estar criado, nada impediu a exigência de sua reestruturação, a partir de determinado marco jurídico pré-estabelecido, distante do espírito da eclesiologia do Vaticano II.

O imperativo de uma reforma das estruturas da Igreja, em vista de um efetivo exercício da sinodalidade eclesial, leva a retomar a questão do estatuto teológico das Conferências Episcopais, seja de seu lugar no exercício da sinodalidade eclesial, seja em relação à sua função magisterial.

\section{Sinodalidade eclesial e colegialidade episcopal}

O exercício da colegialidade episcopal, através do novo coetus episcoporum que são Conferências Episcopais Nacionais e Continentais, está estreitamente unido à sinodalidade da Igreja, tal como atesta seu itinerário histórico. Para K. Rahner, os concílios particulares, provinciais ou regionais que foram se realizando espontaneamente na história, em ordem à solicitude pastoral das Igrejas, constituem a pré-história das Conferências Episcopais ou seu fundamento remoto. ${ }^{1}$ Em outras palavras, há uma analogia entre concílios particulares e conferências episcopais, estas, nascidas um século antes de serem formalmente instituídas e regulamentadas por Pio X. Também na Igreja, em muito, as práticas têm se antecipado à teoria, o que mostra a primazia da ortopráxis em relação à ortodoxia. ${ }^{2}$ A verdade, também no seio da fé cristã, precisa passar pelo crivo da veracidade, de sua comprovação histórica.

CoubeaoPapaPioX(1903-1914) darinstitucionalização eregulamentação jurídica às Conferências Episcopais Nacionais, as quais finalmente passam a ter caráter oficial. O Papa, acertadamente, as situa em relação de estreita analogia

\footnotetext{
${ }^{1}$ ANTON, A., Conferencias episcopales, p. 274.

${ }^{2}$ BRIGHENTI, A., A irrelevância magisterial das conferências episcopais à luz do Vaticano II, p. 306-327.
} 
com os concílios particulares, aludindo inclusive a uma parcial substituição dos concílios particulares pelas conferências episcopais nacionais. ${ }^{3}$ Entretanto, historicamente, o medo do novo e o centralismo da Cúria romana, pouco a pouco, farão as Conferências Episcopais Nacionais perderem a autonomia que as viu nascer. Através de decreto, se determina que antes de uma conferência se reunir, se informe a Santa Sé e se lhe envie, posteriormente, as atas de cada sessão de trabalho, bem como as decisões tomadas. ${ }^{4}$

Ora, isso não ocorria em relação aos concílios particulares, muito menos na forma como se realizaram as Conferências Gerais dos Bispos da América Latina e do Caribe. Por ocasião da Primeira Conferência Geral, realizada no Rio de Janeiro em 1955, se decreta: as Conferências Gerais só podem acontecer quando a Sé Apostólica decida convocá-la; a agenda é definida pela Santa Sé; um delegado pontifício será um dos presidentes da Conferência; membros da Cúria romana serão membros da Conferência com direito a intervir nas sessões e a votar; e as conclusões da assembleia devem ser aprovadas por Roma. Só com o Concílio Vaticano II as Conferências Episcopais ganhariam mais autonomia e confiança. Mas, por pouco tempo. ${ }^{5}$

\subsection{A Igreja como Igreja de Igrejas Locais}

Os anos de dinamismo e maior autonomia das Conferências Episcopais vão do final do Vaticano II até à realização do Sínodo, realizado em 1985, para celebrar os 20 anos do Concílio. Às vésperas deste Sínodo, o então Cardeal Joseph Ratzinger, Prefeito da Congregação para a Doutrina da Fé, atribui às Conferências Episcopais um papel meramente pragmático e funcional. Afirmava ele, na ocasião:

As Conferências Episcopais não têm uma base teológica, não fazem parte da estrutura imprescindível da Igreja tal como a quis Cristo; somente têm uma função prática, concreta... Nenhuma Conferência Episcopal tem, enquanto tal, uma missão magisterial; seus documentos não têm um valor específico, exceto o valor do consenso que lhes é atribuído por cada Bispo. ${ }^{6}$

\footnotetext{
${ }^{3}$ FELICIANI, G., Le conferenze episcopali, p. 165.

${ }^{4}$ PIO X, PP., Decr. De relationibus dioecesanis et visitatione SS. Liminum.

${ }^{5}$ BRIGHENTI, A., Igreja de Igrejas e Colegialidade.

${ }^{6}$ RATZINGER, J.; MESKORI, V., Informe sobre la fe, p. 68.
} 
A repercussão do posicionamento da Cúria romana foi grande, provocando reações distintas. Por um lado, o questionamento do estatuto teológico das Conferências Episcopais Nacionais estimulou teólogos da envergadura de Y. Congar, K. Rahner e A. Anton, atores e reconhecidos intérpretes do Concílio Vaticano II, a dar uma fundamentação teológica às Conferências Episcopais, ${ }^{7}$ ancorada no magistério, especialmente do período patrístico. Por outro lado, frente à posição da Cúria, entretanto, o resultado deste esforço foi nulo, pois, apesar das evidências do ponto de vista eclesiológico, nada impediu a exigência de uma nova regulação jurídica das Conferências Episcopais, através da reforma de seus estatutos dentro de certos parâmetros, distantes de sua verdadeira identidade e papel exercido no período pós-conciliar.

O questionamento do estatuto teológico das Conferências Episcopais se funda na eclesiologia reinante na Igreja durante o segundo milênio, superada pelo Concílio Vaticano II: existe uma Igreja Universal que precede e acontece nas Igrejas Locais, da qual o Papa é o representante e o garante. As Dioceses são "parcela" da Igreja universal e, consequentemente, os bispos são colaboradores do Papa, que por sua vez, é o bispo dos bispos. Tal concepção de Igreja dispensa toda e qualquer instância intermédia entre a Igreja de Roma e as Igrejas Locais. Já a eclesiologia conciliar, em sua volta às fontes bíblicas e patrísticas, afirma a catolicidade da Igreja em cada Igreja Local, em comunhão com as demais Igrejas. Não há Igreja nem anterior e nem exterior às Igrejas Locais. Em outras palavras, não existe Igreja fora da concretude da Igreja Local. Para o Vaticano II, a Diocese é "porção" do Povo de Deus, não "parte" (a porção contém o todo, já a parte não). Nela está "toda a Igreja", pois cada Igreja Local é depositária da totalidade do mistério de salvação, ainda que ela não seja a "Igreja toda", pois nenhuma delas esgota este mistério.

À luz do Concílio, uma suposta Igreja universal, que precede e acontece nas Igrejas Locais, da qual o Papa é o representante e o garante, foi classificada por W. Kasper de uma ficção eclesiológica. A Igreja una é "Igreja de Igrejas", conjugando autonomia e comunhão com as demais Igrejas, presidida pelo Bispo da Igreja de Roma. A sinodalidade é intrínseca ao ser da Igreja; enquanto "assembleia",

\footnotetext{
${ }^{7}$ CONGAR, Y., Collège, Primauté... Conférences episcopales; CONGAR, Y., Autonomie et pouvoir centrale dans l'Église vu par la théologie catholique; ANTON, A., Conferencias episcopales, instancias intermedias?; ANTON, A., El estatuto teológico de las conferencias episcopales, p. 233-268; LEGRAND, H.; MANZANARES, J.; GARCÍA Y GARCÍA, A., Le Conférences épiscopales; RAHNER, K., Sobre el concepto de "ius divinum" en su comprensión católica, p. 247-274.
} 
sinodalidade é o nome da Igreja. No modelo eclesial neotestamentário, as Igrejas que vão nascendo, não se constituem em "Igrejas de", materializando uma suposta Igreja universal que as precede, mas "Igrejas em", a mesma e única Igreja, que está toda (inteira) em cada Igreja Local, que se configura, não como uma filial ou cópia de uma suposta "Igreja mãe", mas uma Igreja diferente, com rosto próprio, culturalmente nova, universal nas particularidades.

\subsection{A relação intrínseca entre sinodalidade eclesial e colegialidade episcopal}

Para responder ao questionamento do estatuto teológico das Conferências Episcopais Nacionais, é preciso remeter-se ao exercício da colegialidade episcopal, que por sua vez não é algo que se dá à margem da sinodalidade eclesial. ${ }^{8}$ A colegialidade se dá não no sentido vertical, do Colégio dos Bispos como o Papa. Por um lado, o bispo preside uma Igreja Local, da qual ele é também membro e, portanto, precisa exercer seu ministério de modo sinodal com todo o Povo de Deus, presente em sua Igreja. Por outro, sua Igreja, enquanto Igreja de Igrejas, situa o bispo no seio de um único Colégio, presidido pelo Bispo da Igreja de Roma, na solicitude das Igrejas, de modo sinodal. Em outras palavras, é na comunhão do bispo com seu Povo e de sua Igreja com as demais Igrejas Locais, que acontece a sinodalidade eclesial.

Assim, sinodalidade eclesial e colegialidade episcopal são modos do ser eclesial, constitutivos do seu ser, que remetem ao próprio sentido do termo

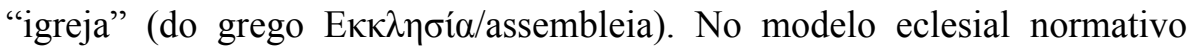
neotestamentário, tudo na Igreja diz respeito a todos os membros da comunidade eclesial, mesmo que a Igreja seja uma comunidade organizada, com diferentes ministérios. Historicamente, a comunidade eclesial como um todo até o século III e no Egito ainda durante todo o século IV, tinha um papel decisivo na Igreja, inclusive na eleição de seus bispos ou presbíteros. ${ }^{9}$ É uma questão de lógica: se todos os batizados são membros da Igreja ou são plenamente membros ou não são. Tanto que o termo "leigo" só irá aparecer na Igreja no século III, quando justamente começa o processo de uma gradativa cisão entre ministérios ordenados e não ordenados, entre sinodalidade eclesial e colegialidade episcopal. No seio da comunidade eclesial, em lugar de um

${ }^{8}$ LYONNET, S., A Colegialidade Episcopal e seus Fundamentos Escriturísticos, p. 821-838.

9 "Nenhum bispo imposto" é um princípio do período patrístico, que as Igrejas prezam muito. Quando se começou a descumprir a regra, apareceram os denominados "bispos vagos", isto é, sem Igreja. A este respeito ver a obra de GONZÁLEZ FAUS, J. I., Nenhum Bispo Imposto. 
único gênero de cristãos - os batizados, passaram a existir duas classes de pessoas - os clérigos e a "aqueles que não são clérigos", os leigos. ${ }^{10} \mathrm{Em}$ consequência, entre outros, a comunidade eclesial perderá seu direito de eleger seus próprios bispos ou presbíteros.

$\mathrm{Na}$ eclesiologia resgatada das fontes pelo Concílio Vaticano II, o sujeito da Igreja é todo o Povo de Deus, pois os batizados, como um todo, são o sujeito que acolhe a Revelação. A mensagem de salvação e a missão não são algo que recai sobre o Povo de Deus ou sobre uma Igreja já constituída em si mesma e que, num segundo momento, se tornaria atuante. Revelação e atuação são realidades intrínsecas e constitutivas da própria Igreja, de modo que a colegialidade e a decorrente função magisterial não podem ser concebidas fora do contexto da sinodalidade eclesial. ${ }^{11}$ Expressão da sinodalidade da Igreja é o sensus fidei ou o sensus fidelium, de onde decorre a legitimidade de uma "opinião pública" na Igreja, reconhecida inclusive pelo Direito Canônico. ${ }^{12}$ O eclipse do sensus fidelium significa operar uma cisão entre sinodalidade eclesial e colegialidade episcopal. Em outras palavras, é conceber o Colégio como um grupo de pessoas que tem poder "sobre" e não "na" Igreja, como se não fossem os bispos também membros da Igreja que presidem e de um Colégio que os vincula à solicitude das Igrejas como um todo. ${ }^{13}$

Foi na vivência da sinodalidade que a Igreja nascente foi criando formas de exercício da colegialidade dos Bispos, segundo as necessidades que foram se apresentando na obra da evangelização, fossem elas de caráter doutrinário, pastoral ou administrativo. No passado, como instâncias intermédias entre a Igreja Local e a comunhão das Igrejas, nasceram os concílios particulares e provinciais. De forma analógica, nos últimos tempos, dado o surgimento dos Estados nacionais e a emergência de desafios pastorais que ultrapassam as fronteiras da Igreja Local, nasceram as Conferências Episcopais Nacionais e Continentais. Assim, tal como os concílios particulares e regionais, as Conferências Episcopais são de direito eclesiástico, mas fundadas no direito

${ }^{10}$ CONGAR, Y., Jalons pour une théologie du laïcat, p. 390-391.

${ }^{11}$ ANTON, A., Conferencias episcopales, instancias intermedias?, p. 388-389.

12 CIC Cân. 212, §3: "Os féis, segundo a ciência, a competência e a proeminência de que desfrutam, têm o direito e mesmo por vezes o dever, de manifestar aos sagrados Pastores a sua opinião acerca das coisas atinentes ao bem da Igreja e de a exporem aos restantes fiéis, salva a integridade da fé e dos costumes, a reverência devida aos Pastores, e tendo em conta a utilidade comum e a dignidade das pessoas". Ver, também: GUTIERREZ, J. L., El principio de subsidiariedad y la igualdad radical de los fieles, p. 437-443.

${ }^{13}$ Aqui, seguirei de perto a posição de LEGRAND, H., The Ministry of the Pope, p. 99-127. 
divino, pois são expressão das diferentes instâncias ou organismos de um mesmo e único Colégio, que opera no seio de uma Igreja essencialmente sinodal. Isso não significa que a Igreja esteja em sínodo permanente. Mas, os concílios, sínodos e assembleias de Conferências Episcopais são realizações ou atos concretos do ser sinodal da Igreja, ao qual está vinculado o colégio dos Bispos. ${ }^{14}$

Em resumo, na Igreja, sinodalidade e colegialidade estão intimamente imbricadas. Tanto que os próprios ministérios de presidência das Igrejas Locais, espelhados no colégio dos apóstolos, não nasceram de modo monárquico, ${ }^{15}$ mas sinodal. Na Igreja primitiva e ainda em boa parte do período patrístico, a

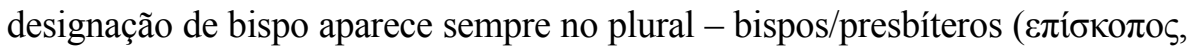
$\pi \rho \varepsilon \sigma \beta v \tau \varepsilon \rho \circ \varsigma)$. Os cristãos eram conscientes de que a apostolicidade da Igreja se remete ao "colégio" apostólico, do qual os bispos/presbíteros constituem um colégio de seus sucessores, com a missão de presidir uma Igreja toda ela sinodal.

\subsection{O primado da sinodalidade eclesial sobre a colegialidade episcopal}

Apesar das evidências teológicas, infelizmente, pouco a pouco se foi operando uma ruptura entre sinodalidade eclesial e colegialidade episcopal. Ela se deu, concretamente, quando se perdeu o sentido sacramental da ordenação episcopal. A "ordenação" passou a ser "sagração" episcopal, ou seja, foi reduzida à transmissão, por graça, da sacra potestas entre aqueles que a conferem e aquele que a recebe, sem que a assembleia da Igreja Local exerça neste ato qualquer função. Às vezes, nem mesmo existe Igreja Local, dado que alguém é ordenado bispo, não para presidir uma Igreja, mas para legitimar um episcopado de dignidade funcional ou até para conferir-lhe prestígio no exercício de alguma função burocrática. ${ }^{16}$

Com isso, a união recíproca entre o Bispo e a sua Igreja, simbolizada no anel episcopal, se enfraquece. O Código de Direito Canônico de 1917 iria abolir todo direito de participação por parte de uma Igreja Local na escolha

\footnotetext{
${ }^{14}$ ANTON, A., Conferencias episcopales, instancias intermedias?, p. 273.

${ }^{15}$ Normalmente, nas Igrejas primitivas havia um grupo ou equipe de bispos/presbíteros, que presidiam a Eucaristia nos domingos, por rodízio.

${ }^{16} \mathrm{Na}$ Igreja Antiga, quando as comunidades eclesiais foram impedidas de elegerem seus bispos, elas protestaram e muitas delas não acolhiam seu bispo imposto, fazendo aparecer um grande número de "bispos vagos", sem Igreja, que passaram a provocar desordem, pois ficavam buscando colocação em alguma Igreja.
} 
do seu Bispo. ${ }^{17}$ É como se o Bispo se tornasse membro do Colégio mais pela nomeação por parte do Papa do que por sua ordenação no seio de uma Igreja Local, o que dá margem ao Colégio a exercer um poder "sobre" a Igreja e não um poder "na" Igreja. Em outras palavras, o poder se torna mais importante que a comunhão, perdendo-se, com isso, o primado da sinodalidade eclesial sobre a colegialidade episcopal, ou o que é pior, passa a haver o primado da colegialidade episcopal sobre a sinodalidade eclesial.

O Código de Direito Canônico de 1983, apesar da nova eclesiologia do Vaticano II ${ }^{18}$ continua distante da grande tradição eclesiológica, cujo conceito central em relação à colegialidade episcopal era a communio ecclesiarum ou a sinodalidade eclesial. Concretamente, se explicita o que são leigos e clérigos, o papa, o colégio dos Bispos, o sínodo dos Bispos, os cardeais, a Cúria romana e os núncios, antes de se estabelecer o que é uma Igreja Local e o que é a comunhão das Igrejas. ${ }^{19} \mathrm{Em}$ outras palavras, apresenta-se o Colégio como um grupo de pessoas que existe anteriormente à consideração da Igreja como communio ecclesiarum e independente da comunhão das Igrejas entre si. A presença de tamanho déficit eclesiológico no novo Código, mesmo depois do Concílio Vaticano II, se deve ao fato de não se ter explicitado suficientemente a articulação entre o collegium episcoporum e a communio ecclesiarum. A Lumen Gentium diz como é que alguém se torna membro do colégio: "O novo membro do corpo episcopal é constituído em virtude da consagração sacramental e mediante a comunhão hierárquica com a cabeça e com os membros do respectivo colégio"; ${ }^{20}$ mas, silencia que o novo Bispo passa a ser membro do Colégio, não pela nomeação episcopal pelo Papa, mas pelo fato de ter sido ordenado para uma Igreja Local. ${ }^{21}$

Entretanto, dado que o colegium episcoporum se situa no seio da communio ecclesiarum, na realidade, há o primado da sinodalidade eclesial sobre a colegialidade episcopal. Em outras palavras, a colegialidade episcopal radica no seio de uma Igreja essencialmente sinodal. A Igreja é congregatio fidelium em virtude do Batismo, o que faz de toda a comunidade eclesial um

\footnotetext{
${ }^{17}$ CIC can. 329, §2 ("eos libere nominat Romanus Pontifex").

${ }^{18}$ A este respeito, ver a obra de PHILIPS, G., L'Eglise et son mystère au IIe.

${ }^{19}$ Como se pode constatar no Código de 1983, o Livro II apresenta sucessivamente o estatuto dos fiéis leigos e clérigos (Parte I), a suprema autoridade da Igreja, o romano pontífice e o colégio dos bispos (Parte II, Seção I), depois as Igrejas particulares e os bispos (Parte II, Seção II).

${ }^{20}$ LG 22.

${ }^{21}$ LEGRAND, H., La réalisation de l'Église en un lieu, p. 300.
} 
povo profético, sacerdotal e régio. Mas, sobretudo, por ser o Povo de Deus como um todo o depositário da Revelação, da qual ele é também constitutivo, ${ }^{22}$ o magistério da Igreja, seja do Papa, seja dos Bispos, não está separado da sinodalidade eclesial. ${ }^{23}$ Afirma a Dei Verbum, que incumbe "ao povo cristão inteiro, unido a seus pastores", a missão de perpetuar fielmente a Revelação. ${ }^{24}$ Consequentemente, todo fiel cristão, incorporado à comunidade eclesial em virtude do Batismo, torna-se solidariamente responsável, com os demais batizados, por toda a Igreja. ${ }^{25} \mathrm{Se}$ assim não fosse, a Igreja não seria uma Igreja de Igrejas, mas uma mera casta de Bispos.

\section{Colegialidade episcopal e Magistério}

Para assegurar a unidade da fé, está o magistério. Diz o Vaticano II que a Igreja una e única se realiza na Igreja Local (in quibus), em comunhão com as demais Igrejas (ex quibus). Dado que a colegialidade episcopal se situa no seio da sinodalidade eclesial, também a função magisterial se dá no seio do Povo de Deus, fruto de um mútuo dar e receber entre todos os membros da comunidade, no respeito pelo lugar que cada um ocupa na Igreja. ${ }^{26} \mathrm{E}$ mais que isso: como há o primado da sinodalidade eclesial sobre a colegialidade episcopal, há também o primado do Povo de Deus ou do sensus fidelium sobre o magistério. Como a Igreja é una, também uno é o magistério, ainda que em diferentes níveis, dado que o Povo de Deus é um povo organizado.

\subsection{Sinodalidade, colegialidade e magistério}

O magistério uno no seio de uma Igreja una, se dá basicamente em três níveis. Em um primeiro nível, está o magistério universal, garante da catolicidade da fé no seio de uma Igreja una, na diversidade das Igrejas, presididas pelo Bispo de Roma. ${ }^{27} \mathrm{O}$ magistério universal é competência do primado, cabeça do colégio, e dos demais membros bispos do mesmo, a ser

\footnotetext{
${ }^{22} \mathrm{DV} 7$.

${ }^{23}$ CONGAR, Y., Vraie et fausse réforme dans l’Église, p. 242.

${ }^{24}$ DV 10; ANTÓN, A., La comunidad creyente, portadora de la revelación, p. 332-333.

${ }^{25}$ LG $12,17$.

${ }^{26}$ ANTÓN, A., Conferencias episcopales, instancias intermedias?, p. 390. Ver, também, SESBOÜÉ, B., La notion de magistère dans l'histoire de l'Église et de la théologie, p. 17-61.

${ }^{27}$ LG 25c.d; DV 10b; KASPER, W., Teologia e Chiesa, p. 290.
} 
exercido quer reunido em concílio, quer pela comunicação entre os bispos dispersos pelo mundo. Ao magistério universal cabe autenticar a fé da congregatio fidelium, na qual também ele está também inserido.

Um segundo nível do magistério uno na Igreja una, é o magistério inerente a cada Bispo. Dado que a Igreja é "Igreja de Igrejas", o Bispo em sua Diocese, em virtude de se lhe haver confiado uma Igreja Local e ter recebido a ordenação episcopal, exerce seu ministério, não apenas em sua Igreja, mas participa da solicitude das Igrejas, cum e sub sucessore Petri, em comunhão com todos os demais membros do colégio episcopal. Consequentemente, seu ministério não deriva do Papa e nem é outorgado por ele, mas recebe de Deus, em função de sua nomeação para uma Igreja Local, seguida da ordenação. Portanto, trata-se de um ministério próprio, de direito divino. Historicamente, para expressar o caráter colegial do ministério episcopal, o Concílio de Nicéia (325) definiu sua ordenação por ao menos três Bispos de Igrejas vizinhas, dado que a ordenação incorpora o neo-ordenado Bispo no corpus episcoporum. Na Igreja antiga, este caráter colegial do ministério episcopal era ainda muito mais evidente, dado que o episcopado não era monárquico. ${ }^{28}$ Era costume e em certas regiões durante séculos, haver na Igreja Local um grupo de Bispos, que inclusive presidia a Eucaristia dominical por rodízio. Também o ministério que se denominará mais tarde "presbiteral", depois diferenciado do ministério episcopal, será igualmente colegiado, uma equipe de presbíteros à frente de uma comunidade eclesial.

Um terceiro nível do "magistério uno" no seio de uma "Igreja una", é o magistério de instâncias intermédias entre o Primado do Bispo da Igreja de Roma - o magistério universal, e o Bispo em sua Igreja Local, tal como foram no passado os concílios particulares. É inegável que os concílios particulares, sejam eles provinciais ou regionais, exerceram um magistério na Igreja, sobretudo durante o primeiro milênio. É verdade que os concílios particulares, enquanto criados pelas Igrejas são de direito eclesiástico, mas dada sua referência ao "magistério uno" no seio de uma "Igreja una", estão também eles fundados no direito divino. Em consequência, como a Igreja é Igreja de Igrejas, quando parte do colégio dos Bispos se reúne, na solicitude pelas Igrejas de uma região, cum e sub sucessore Petri, dado que o Bispo não recebe sua função magisterial por quem lhe nomeia ou ordena, mas em virtude do sacramento que lhe é conferido, também exerce um magistério.

${ }^{28}$ RAHNER, K., Sobre El episcopado, p. 359-412. 
O questionamento da autenticidade magisterial e mesmo da utilidade de instâncias intermédias na Igreja, como as Conferências Episcopais, não é de hoje. A partir do Concílio de Trento, com a centralização do governo da Igreja no Papa e na Cúria romana e o consequente eclipse do metropolita e o esvaziamento da função dos concílios particulares, durante vários séculos na Igreja não houve outro magistério que o do Papa e do Bispo diocesano. ${ }^{29}$ Houve Papas que pensaram inclusive na inutilidade dos próprios concílios plenários ou ecumênicos, justificando que estavam em permanente comunicação com os Bispos à distância ou por ocasião das visitas ad limina apostolorum.

\subsection{Conferências Episcopais e Magistério}

Dado que a colegialidade episcopal, em suas diferentes instâncias, é a expressão do exercício da sinodalidade eclesial ou dado que o collegium episcoporum se insere no seio da communio ecclesiarum, teologicamente, reduzir o papel das Conferências Episcopais a uma finalidade pragmática e funcional carece de fundamentação teológica. ${ }^{30}$ Primeiro porque, eclesiologicamente, não se sustenta um conceito de unidade da Igreja, que justifique um governo central e a imposição de uma uniformidade de doutrina e de disciplina sobre todas as Igrejas Locais. Isso comprometeria a legítima diversidade e pluriformidade das Igrejas, enquanto "Igreja de Igrejas". A Igreja una e católica se realiza nas Igrejas Locais (in quibus) e entre elas (ex quibus). Segundo, reduzir o papel das Conferências Episcopais a uma finalidade pragmática e funcional carece de fundamentação porque também não se sustenta uma tal autonomia do Bispo diocesano, que o isole dos postulados da comunhão com as demais Igrejas e sua integração com os demais Bispos, irmãos no episcopado e membros de um único Colégio. Um bispo que se isola e isola sua Igreja das demais Igrejas, coloca-se fora da Igreja. A unidade com a Igreja de Roma passa pela unidade com todas as demais Igrejas.

A fundamentação teológica das Conferências Episcopais e sua consequente função magisterial dependem, portanto, da relação in quibus e ex quibus das Igrejas Locais, incluída a Igreja de Roma e o ministério petrino, cabeça do colégio dos Bispos. A relação entre a Igreja una e as muitas Igrejas

\footnotetext{
${ }^{29}$ MULLER, H., La conferencia episcopal y el obispo diocesano, p. 153-154.

${ }^{30}$ Essa cisão se dá quando o colégio é concebido como um grupo de pessoas que tem poder sobre a Igreja universal, prescindindo da comunhão das Igrejas como um todo entre si.
} 
está clara no Concílio Vaticano II. ${ }^{31}$ Por um lado, absolutizar in quibus, significa conceber a Igreja católica fragmentada em Igrejas Locais, como Igrejas autônomas e, com isso, volatizando a catolicidade. A Igreja católica, ao invés de ser uma Igreja una, seria uma congregação de Igrejas. Por outro lado, absolutizar ex quibus, significa anular a catolicidade em cada Igreja Local, fazendo delas "parte" e não "porção" do Povo de Deus, como afirma o Concílio. ${ }^{32}$ Como vimos, a porção contém o todo, a parte, não. ${ }^{33}$

Com extrema prudência, o Concílio Vaticano II não emprega o termo "colegialidade", mas "colégio" dos Bispos, entendido este como o conjunto do corpo dos Bispos, que constituem com o Romano Pontífice, sua Cabeça, uma comunhão hierárquica estável e indivisível. É preciso, entretanto, ter presente o que o Concílio entende por "indivisível”. Poder-se-ia pensar, por exemplo, como a atuação do colégio inteiro dos Bispos ou nada. Entretanto, o Vaticano II fala de duas "ações estritamente colegiais": uma quando exercida de modo solene no concílio plenário e outra fora dele, sempre que se dê o consentimento livre do sucessor de Pedro (uma vez que se trata de membros de um colégio cum e sub Petri). Neste segundo caso, também a ação colegial pode dar-se de dois modos: quando o Cabeça do Colégio convida a uma ação colegial ou quando aceita livremente a ação colegial dos Bispos à frente das Igrejas Locais. ${ }^{34}$ Trata-se de "formas parciais" da colegialidade, que se denomina de "efeito colegial", "união colegial" ou "solicitude de todas as Igrejas". ${ }^{35}$ As "formas parciais" não estão desprovidas de verdadeiro exercício da colegialidade, pois elas são fruto do "ato estritamente colegial", dado que também se fundam no Colégio. É sobre esta base teológica que o Vaticano II, na Christus Dominus, aprova e recomenda as Conferências Episcopais Nacionais,$^{36}$ desautorizando, portanto, reservar a elas uma finalidade puramente pragmática e funcional.

Assim, por um lado, as Conferências Episcopais de modo algum põem em questão a autoridade do Primado (cabeça do Colégio) e tampouco comprometem a autonomia do Bispo diocesano à frente de sua Igreja Local. Não se pode perder de vista que, de um lado, o ius divinum do ministério petrino, coexiste na Igreja com todos os membros do episcopado e, de outro,

\footnotetext{
${ }^{31}$ LG 23a.

${ }^{32}$ ANTÓN, A. Conferencias episcopales, instancias intermedias?, p. 385.

${ }^{33}$ LEGRAND, H., La réalisation de l'Église en un lieu, p. 145-146.

${ }^{34}$ LG 22.

${ }^{35}$ LG 23.

${ }^{36} \mathrm{CD} 38 \mathrm{a}$.
} 
que o Bispo diocesano não esgota o ius divinum, uma vez que a Igreja é "Igreja de Igrejas".

\section{Conclusão}

As Conferências Episcopais, sejam elas nacionais ou continentais, estão muito aquém do que foram os concílios particulares na Igreja, durante mais de um milênio, os quais constituem sua pré-história. Reservar às Conferências Episcopais um papel pragmático e funcional equivale a negar a sinodalidade do ser da Igreja, no seio da qual se insere a colegialidade episcopal. Subjacente a esta postura está uma eclesiologia superada pelo Concílio Vaticano II, segundo a qual há uma suposta Igreja universal anterior e exterior às Igrejas Locais. Nesta concepção, as Igrejas Locais são parcelas da Igreja universal, presidida pelo papa, o bispo dos bispos. Segundo K. Rahner, a principal mudança do Vaticano II é o resgate da catolicidade da Igreja em cada Igreja Local, "porção" e não "parte" do Povo de Deus. ${ }^{37}$ Para o Vaticano II, a catolicidade não é uma particularidade que estende e se impõe sobre as demais particularidades, absorvendo-as e aniquilando-as. Nem uma tal autonomia das Igrejas Locais, que faria da Igreja uma confederação de Igrejas autônomas. A Igreja é Igreja de Igrejas, inserindo a colegialidade episcopal no seio da sinodalidade eclesial. O exercício da colegialidade episcopal, no seio de uma Igreja toda ela sinodal, faz das instâncias intermedias entre as Igrejas Locais e a Igreja Local de Roma, como são as Conferências Episcopais, a condição para superar tanto um universalismo generalizante, quanto diocesanismos estreitos.

Assim, dado que a colegialidade episcopal, em suas diferentes instâncias, é a expressão do exercício da sinodalidade eclesial, reduzir o papel das Conferências Episcopais a uma finalidade pragmática e funcional carece de fundamentação teológica. A Igreja una e católica se realiza nas Igrejas Locais (in quibus) e entre elas (ex quibus). Tal como os concílios particulares e regionais, as Conferências Episcopais são de direito eclesiástico, mas fundadas no direito divino, pois são expressão das diferentes instâncias ou organismos de um mesmo e único Colégio, que opera no seio de uma Igreja essencialmente sinodal. Por sua vez, a legitimidade de instâncias intermedias no exercício da sinodalidade eclesial assegura também um papel magisterial às Conferências Episcopais. Além do magistério universal, garante da catolicidade da fé no

${ }^{37} \mathrm{CD} 11 \mathrm{a}$. 
seio de uma Igreja una, assim como do magistério inerente a cada bispo em sua Diocese, não é um despropósito conferir um papel magisterial à instâncias intermédias entre o Primado e o Bispo na Igreja Local, tal como foram no passado os concílios particulares. Quando parte do Colégio dos Bispos se reúne, na solicitude pelas Igrejas de uma região, cum e sub sucessore Petri, dado que o Bispo não recebe sua função magisterial de quem the nomeia ou ordena, mas em virtude do sacramento que lhe é conferido, também ele exerce um magistério.

\section{Referências bibliográficas}

ANTÓN, A. Conferencias episcopales, instancias intermedias? El estado teológico de la cuestión. Salamanca: Sígueme, 1989. (Verdad e imagen, 111). ANTÓN, A. El estatuto teológico de las conferencias episcopales. In: LEGRAND, H.; MANZANARES, J; GARCÍA Y GARCÍA, A. Naturaleza y futuro de las conferencias episcopales. Salamanca: Sígueme, 1988. p. 233268.

ANTÓN, A. La comunidad creyente, portadora de la revelación. In: ALONSO SCHÖKEL, L. (Dir.). Comentarios a la constitución Dei Verbum sobre la divina revelación. Madrid: La Editorial Católica, 1969. p. 311-364.

BRIGHENTI, A. A irrelevância magisterial das conferências episcopais à luz do Vaticano II. In: BRIGHENTI, A.; ARROYO, F. M. (Orgs.). O Concílio Vaticano II: batalha perdida ou esperança renovada? São Paulo: Paulinas, 2015. p. 306-327.

BRIGHENTI, A. Igreja de Igrejas e Colegialidade: as conferências episcopais nacionais à luz do Vaticano II. Studium, v.6, n.11, p. 55-71, jan./jun. 2012.

CONCÍLIO VATICANO II. Constituição Dogmática Dei Verbum. In: COMPÊNDIO DO VATICANO II. Constituições, Decretos, Declarações. Petrópolis: Vozes, 1968. p. 121-139.

CONCÍLIO VATICANO II. Constituição Dogmática Lumen Gentium. In: COMPÊNDIO DO VATICANO II. Constituições, Decretos, Declarações. Petrópolis: Vozes, 1968. p. 39-117.

CONCÍlIO VATICANO II. Decreto Christus Dominus. In: COMPÊNDIO DO VATICANO II. Constituições, Decretos, Declarações. Petrópolis: Vozes, 1968. p. 403-436. 
CÓDIGO de Direito Canônico. São Paulo: Loyola, 2001.

CONGAR, Y. Autonomie et pouvoir centrale dans l'Église vu par la théologie catholique. Kanon, n.4, p. 130-144, 1980.

CONGAR, Y. Collège, Primauté... Conférences episcopales: quelques notes. Esprit et Vie, n.96, p. 385-390, 1986.

CONGAR, Y. Jalons pour une théologie du laïcat. Paris: Cerf, 1953.

CONGAR, Y. Vraie et fausse réforme dans l'Église. Paris: Cerf, 1968.

FELICIANI, G. Le conferenze episcopali. Bologna: Quirinali, 1974.

FRANCISCO, PP. Exortação Apostólica Evangelli Gaudium. São Paulo: Paulinas, 2013.

GONZÁLEZ FAUS, J. I. Nenhum Bispo Imposto. As Eleições Episcopais na História da Igreja. São Paulo: Paulus, 1996.

GUTIERREZ, J. L. El principio de subsidiariedad y la igualdad radical de los fieles. IusCan, n. 11, p. 437-443, 1971.

KASPER, W. Teologia e Chiesa. Brescia: Queriniana, 1989.

LEGRAND, H. La réalisation de l'Église en un lieu. In: LAURET, B.; REFOULÉ, F. (Org.). Initiation à la pratique de la théologie. Paris: Cerf, 1983. p. 143-345. t.III/2.

LEGRAND, H. ; MANZANARES, J. ; GARCÍA Y GARCÍA, A. Le Conférences épiscopales. Theologie, statut canonique, avenir. Paris: Cerf, 1988.

LEGRAND, H. The Ministry of the Pope: Primacy and Collegiality in Vatican II. In: DOS ANJOS, M. F. (Org.). Bispos para a esperança do mundo: uma leitura crítica sobre caminhos de Igreja. São Paulo: Paulinas, 2000. p. 99-127.

LYONNET, S. A Colegialidade Episcopal e seus Fundamentos Escriturísticos. In: BARAÚNA, G. (Org.). A Igreja do Vaticano II. Petrópolis, RJ: Vozes, 1965. p. 821-838.

MULLER, H. La conferencia episcopal y el obispo diocesano. In: LEGRAND, H.; MANZANARES, J.; GARCÍA Y GARCÍA, A. (Eds.). Naturaleza y futuro de las conferencias episcopales. Salamanca: Sígueme, 1988. p. 153-154. PHILIPS, G. L'Eglise et son mystère au IIe. Concile du Vatican. Histoire, texte et commentaire de la Constitution Lumen gentium. Paris: Ed. du Cerf, 1967. t.I. 
PIO X, PP. Decr. De relationibus dioecesanis et visitatione SS. Liminum (31.12.1909). In: AAS, n.20, p. 20, 1910.

RAHNER, K. Sobre el concepto de "ius divinum" en su comprensión católica. Escritos de Teología, n.5, p. 247-274, 1964.

RAHNER, K. Sobre El episcopado. Escritos de Teología, n.6, p. 359-412, 1969.

RATZINGER, J.; MESKORI, V. Informe sobre la fe. Madrid: Herder, 1985. SESBOÜÉ, B. La notion de magistère dans l'histoire de l'Église et de la théologie. In: SESBOÜÉ, B. Le magistère à l'épreuve. Autorité, vérité et liberté dans l'Église. Paris: Desclée de Brouwer, 2001. p. 17-61.

Agenor Brighenti Doutor em Ciências Teológicas e Religiosas pela Université Catholique de Louvain Docente do Programa de Pós-Graduação em Teologia da Pontifícia Universidade Católica do Paraná Curitiba / PR - Brasil E-mail: agenor.brighenti@pucpr.br

Recebido em: 09/07/2019 Aprovado em: 20/03/2020 